\title{
STUDI EKSPERIMEN PENGGANTIAN AGREGAT KASAR DENGAN TERAK BAJA TERHADAP KUAT TEKAN BETON NORMAL
}

\author{
Ardana Dika Anggara ${ }^{1}$, Anis Rahmawati ${ }^{2}$, Aryanti Nurhidayati ${ }^{3}$ \\ Pendidikan Teknik Bangunan, Universitas Sebelas Maret \\ e-mail: ardanananggara@gmail.com
}

\begin{abstract}
Abstrak : Tujuan penelitian ini adalah (1) mengetahui pengaruh penggantian agregat kasar beton dengan terak baja pada variasi $0 \%, 20 \%, 40 \%, 60 \%, 80 \%$, dan $100 \%$ pada umur 14 hari, 28 hari, 60 hari, dan 90 hari terhadap kuat tekan beton dengan metode campuran 1:2:3, (2) mengetahui beton dengan variasi penggantian terak baja $0 \%, 20 \%, 40 \%, 60 \%, 80 \%$, dan $100 \%$ dengan umur 14 hari, 28 hari, 60 hari, dan 90 hari berdasarkan berat isinya masih termasuk katagori beton normal, dan (3) mengetahui persentase terak baja yang digunakan sebagai pengganti agregat kasar mencapai kuat tekan optimal pada beton umur 14 hari, 28 hari, 60 hari, dan 90 hari dengan metode campuran 1:2:3. Penelitian menggunakan metode eksperimen, dengan sampel beton berbentuk silinder dimensi $150 \mathrm{~mm}$ x $300 \mathrm{~mm}$ terhadap pengujian kuat tekan. Variabel bebas penelitian ini berupa penggantian sebagian agregat kasar dengan terak baja dengan metode campuran perbandingan 1:2:3. Adapun persentase penggantian yang digunakan adalah $0 \%, 20 \%, 40 \%$, $60 \%, 80 \%$, dan $100 \%$ dari volume agregat kasar, sedangkan variasi umur pengujian benda uji adalah 14 hari, 28 hari, 60 hari, dan 90 hari dengan 3 buah sampel setiap variasi penggantian. Pengujian kuat tekan dilakukan dengan CTM (Compressing Testing Machine) menurut SNI 1974-2011. Hasil penelitian sebagai berikut (1) Penggantian terak dan variasi umur berpengaruh terhadap kuat tekan beton terak baja, (2) Berat isi beton normal $\left(2200-2500 \mathrm{~kg} / \mathrm{m}^{3}\right)$ dicapai pada variasi $20 \%, 40 \%$, dan $60 \%$ sedangkan pada variasi $80 \%$ dan $100 \%$ tidak termasuk dalam katagori beton normal $\left(>2500 \mathrm{~kg} / \mathrm{m}^{3}\right)$, (3) Penggantian terak baja dan variasi umur menghasilkan kuat tekan optimal beton terak pada persentase $60 \%$ yaitu $11,78 \mathrm{MPa}$ pada umur 14 hari, 14,05 MPa pada umur 28 hari, 18,29 MPa pada umur 60 hari, dan 20,36 MPa pada umur 90 hari.
\end{abstract}

Kata Kunci: terak baja, agregat kasar, umur beton, kuat tekan, beton terak

\footnotetext{
${ }^{1}$ Mahasiswa Program Studi Pendidikan Teknik Bangunan FKIP UNS

${ }^{2}$ Pembimbing 1 Anis Rahmawati, S.T., M.T.

${ }^{3}$ Pembimbing 2 Aryanti Nurhidayati, S.T., M.Eng.
} 


\title{
EXPERIMENTAL STUDY OF THE COARSE AGGREGATE REPLACEMENT WITH STEEL SLAG ON COMPRESSIVE STRENGTH IN NORMAL CONCRETE
}

\author{
Ardana Dika Anggara ${ }^{1}$, Anis Rahmawati ${ }^{2}$, Aryanti Nurhidayati ${ }^{3}$ \\ Pendidikan Teknik Bangunan, Universitas Sebelas Maret \\ e-mail: ardanananggara@gmail.com
}

\begin{abstract}
The purpose of this research were observed (1) the effect of the influence of the replacement of coarse aggregate concrete with steel slag in the variation of $0 \%, 20 \%, 40 \%, 60 \%, 80 \%$, and 100\% at 14 days, 28 days, 60 days, and 90 days of compressive strength of concrete by using a mixture of 1:2:3, (2) determine the concrete with a variation steel slag replacement of $0 \%, 20 \%, 40 \%, 60 \%, 80 \%$, and $100 \%$ by the age of 14 days, 28 days, 60 days, and 90 days based on the weight of the contents still include the category of normal concrete, and (3) determine the percentage of steel slag used as a substitute for coarse aggregate reach compressive strength optimal in the concrete age of 14 days, 28 days, 60 days, and 90 days with the method a mixture of 1: 2: 3. The research used experimental method, with cylindrical concrete sample dimension $150 \mathrm{~mm} \times 300 \mathrm{~mm}$ against compressive strength test. The independent variables of this research are partial replacement of coarse aggregates with steel slag with a 1:2: 3 mixed ratio method. The percentage of replacements used were 0\%, 20\%, 40\%, 60\%, $80 \%$, and $100 \%$ of the coarse aggregate volume, whereas the test age variations were 14 days, 28 days, 60 days and 90 days with 3 pieces samples of each replacement variation. The compressive strength test was performed by CTM (Compressing Testing Machine) according to SNI 1974-2011. The results of the research were: (1) The replacement of steel slag and age variation affects the compressive strength of the steel slag concrete, (2) The weight of normal concrete content $\left(2200-2500 \mathrm{~kg} / \mathrm{m}^{3}\right)$ was achieved in variations of 20\%, 40\%, and 60\% while in $80 \%$ and $100 \%$ variations not included in normal concrete categories (> $2500 \mathrm{~kg} / \mathrm{m}^{3}$ ), (3) replacements of steel slag and age variation that produces the optimal compressive strength of steel slag concrete at $60 \%$ were the percentage of $11.78 \mathrm{MPa}$ at 14 days, 14.05 MPa at 28 days, $18.29 \mathrm{MPa}$ at the age of 60 days, and 20.36 MPa at age 90 days.
\end{abstract}

Keywords: steel slag, coarse aggregate, concrete age, compressive strength, slag concrete

\footnotetext{
${ }^{1}$ Mahasiswa Program Studi Pendidikan Teknik Bangunan FKIP UNS

${ }^{2}$ Pembimbing 1 Anis Rahmawati, S.T., M.T.

${ }^{3}$ Pembimbing 2 Aryanti Nurhidayati, S.T., M.Eng.
} 


\section{PENDAHULUAN}

Beton menjadi bahan yang paling banyak digunakan dalam mendirikan suatu struktur bangunan. Beton sering digunakan sebagai material utama dalam konstruksi gedung, jembatan, bendungan, jalan, dan irigasi. Menurut Tjokrodimulyo (2004: I-1) beton memiliki kelebihan yaitu harganya relatif murah, termasuk bahan yang awet, tahan aus, tahan kebakaran, tahan terhadap pengkaratan, kuat tekannya cukup tinggi, dan mudah dibentuk sesuai keinginan. Beton normal dalam SNI 7656 (2012: 3) mempunyai berat isi sekitar $2200 \mathrm{~kg} / \mathrm{m}^{3}-2500 \mathrm{~kg} / \mathrm{m}^{3}$, yang dirancang sedemikian rupa dapat menahan kekuatan hancur maupun desakan berdasarkan beban dan dipengaruhi oleh bahan-bahan penyusun, kemudahan pengerjaan (workability), faktor air semen (fas), dan zat tambahan (admixture) bila diperlukan.

Kekuatan beton normal menurut Tjokrodimulyo (2004) akan terus meningkat sampai umur 28 hari, setelah itu tetap terjadi peningkatan tetapi tidak signifikan. Campuran yang digunakan untuk meningkatkan kekuatan tekan beton normal salah satunya adalah menggunakan limbah terak baja.

Terak baja dihasilkan oleh produk sampingan dari proses produksi dapur tinggi dalam pengolahan besi dan baja. Berdasarkan penelitian yang dilakukan Herlangga (2014) kandungan senyawa pada terak baja adalah $\mathrm{SiO}_{2}$ sebesar $35,19 \%, \mathrm{Fe}_{2} \mathrm{O}_{3}$ 19,58\%, $\mathrm{Al}_{2} \mathrm{O}_{3}$ 6,01\%, $\mathrm{MgO} 2,95 \%$, $\mathrm{CaO} 26,51 \%, \mathrm{Na}_{2} \mathrm{O} 3,21 \%$ dengan sampel adalah terak baja dari desa Batur, Kecamatan Ceper, Klaten. Pada penelitian tersebut, dapat diketahui kandungan Silika dioksida $\left(\mathrm{SiO}_{2}\right)$ yang cukup tinggi, sehingga dimungkinkan dapat bereaksi dengan semen.

Limbah ini belum dimanfaatkan secara optimal sebagian hanya digunakan untuk urugan saja bahkan dibiarkan begitu saja. Kuat tekan beton pada umur tertentu akan dipengaruhi oleh kandungan silika. Silika yang terdapat didalam agregat dapat bereaksi dengan alkali pasta semen membentuk suatu gel yang 
akan menyelimuti butiran-butiran agregat dan berlangsung sangat lambat (Tjokrodimulyo, 2004: III31). Terak baja mengandung silika yang akan mulai bereaksi setelah proses hidrasi semen pertama selesai. Namun belum diketahui untuk bahan terak baja sebagai pengganti agregat kasar mempengaruhi kuat tekan beton pada umur lebih dari 28 hari.

Tujuan yang hendak dicapai dalam penelitian ini adalah mengetahui :

1. Pengaruh penggantian agregat kasar dengan terak baja dan umur beton terhadap kuat tekan.

2. Beton dengan penggantian agregat kasar dengan terak baja dan umur beton terhadap berat isinya, termasuk dalam syarat beton normal.

3. Persentase terak pengganti agregat kasar untuk mencapai kuat tekan optimal.

Menurut Tjokrodimulyo (2004: III-4) terak baja (Slag) adalah hasil sampingan dari pembakaran bijih besi pada tanur tinggi yang didinginkan pelan-pelan diudara terbuka.

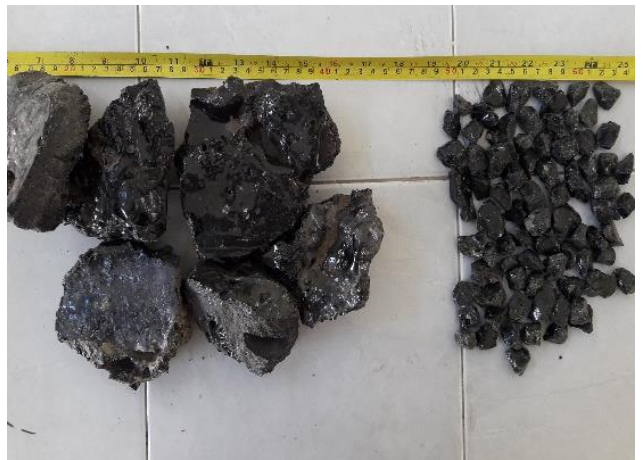

$$
\text { Gambar } 1 \text { Terak Baja }
$$

Nilforoushan \& Reza (2005:

32) menyatakan kandungan silika $\left(\mathrm{SiO}_{2}\right)$ dalam terak akan bereaksi dengan sisa hidrasi semen pertama yang akan membentuk proses hidrasi semen yang kedua. Proses reaksi lanjutan ini menghasilkan kekuatan beton terak meningkat dengan bertambahnya umur beton. Rumus reaksi semen dan silika terak berikut.

1. Semen $+\mathrm{H}_{2} \mathrm{O} \rightarrow \mathrm{CSH}$ (penyemenan gel) $+\mathrm{Ca}(\mathrm{OH})_{2}$

2. $\mathrm{Ca}(\mathrm{OH})_{2}+\mathrm{SiO}_{2} \rightarrow \mathrm{CSH}$

(tambahan gel semen)

Istimawan Dipohusodo (1999) menyatakan bahwa "beton didapat dari pencampuran bahan-bahan agregat halus dan kasar yaitu pasir, batu, batu pecah atau bahan semacam lainnya, dengan menambahkan secukupnya bahan perekat semen, dan air sebagai bahan pembantu guna keperluan reaksi kimia selama proses 
pengerasan dan perawatan beton berlangsung". Sedangkan menurut Kardiyono Tjokrodimulyo (2004: I1) "beton diperoleh dengan cara mencampurkan semen portland, air, dan agregat".

Pencampuran merupakan satu rangkaian yang saling berhubungan dalam pembuatan beton. Satuan perbandingan 1:2:3 mengacu pada PBI 1971 merupakan dalam ukuran volume. Perbandingan 1:2:3 adalah 1 untuk semen, 2 untuk agregat halus (pasir) dan 3 untuk agregat kasar (kerikil/terak). Beton dengan campuran 1:2:3 merupakan campuran yang paling banyak digunakan dalam pembangunan rumah sederhana nonengineering (tanpa keterlibatan insinyur).

Kuat tekan beban beton adalah besarnya beban per satuan luas, yang menyebabkan benda uji beton hancur bila dibebani dengan gaya tekan tertentu, yang dihasilkan oleh mesin tekan. Pengujian kuat tekan dilakukan terhadap beton uji berbentuk silinder atau kubus yang dicetak baik di laboratorium maupun di lapangan, standar ini dibatasi untuk beton yang memiliki berat isi lebih besar dari 800 $\mathrm{kg} / \mathrm{m}^{3}$ (SNI 1974-2011). Asroni (2010: 15) menyatakan bahwa kuat tekan beton diberi notasi dengan $\mathrm{f}_{\mathrm{c}}$, yaitu kuat tekan silinder beton yang disyaratkan pada waktu berumur 28 hari. Bertambarnya umur beton akan menyebabkan kuat tekan beton meningkat. Mulyono (2004: 137) berpendapat "kekuatan beton akan naik secara cepat sampai umur 28 hari, tetapi setelah itu kenaikannya akan kecil". Kekuatan beton dipengaruhi oleh beberapa faktor, salah satunya adalah umur beton. Dalam SNI 1974-2011 waktu pengujian benda uji pada umur 12 jam, 24 jam, 3 hari, 7 hari, 28 hari, dan 90 hari. Sedangkan penelitian yang dilakukan Roslan, dkk. (2016) pengujian beton steel slag dan steel sludge pada umur 3 hari, 7 hari, 28 hari, 60 hari, dan 90 hari. Pengujian kuat tekan dilakukan pada umur 3 hari, 7 hari, 14 hari, 21 hari, 28 hari, dan 90 hari ( Tjokrodimuljo, 2004).

Berat isi beton yaitu perbandingan antara massa beton dengan volume beton. Berat normal dibuat dengan agregat normal (pasir dan kerikil normal berat isinya antara 
2,5-2,7). Menurut SNI 7656: 2012, beton normal adalah beton yang mempunyai berat isi 2200-2500 $\mathrm{kg} / \mathrm{m}^{3}$. Menggunakan agregat alam yang dipecah atau tanpa dipecah yang tidak menggunakan tambahan.

\section{METODOLOGI PENELITIAN}

Metode yang digunakan dalam penelitian ini adalah metode kuantitatif dengan desain penelitian eksperimental.

Persentase penggantian terak baja tehadap volume agregat kasar yaitu $0 \%, 20 \%, 40 \%, 60 \%, 80 \%$, dan $100 \%$, Sedangkan variasi umur pengujian adalah 14 hari, 28 hari, 60 hari, dan 90 hari.

Sampel yang digunakan berupa beton berbentuk silinder dengan diameter $150 \mathrm{~mm}$ dan tinggi $300 \mathrm{~mm}$ sebanyak 12 buah sampel setiap variasi persentase penggantian terak baja, 12 sampel terdiri atas 3 sampel untuk umur 14 hari, 3 sampel untuk umur 28 hari, 3 sampel untuk umur 60 hari, dan 3 untuk umur 90 hari. Jumlah sampel sebanyak 72 buah, lebih rinci dapat di lihat pada tabel 1 .
Tabel 1 Sampel benda uji

\begin{tabular}{|c|c|c|c|c|c|}
\hline variasi & \multicolumn{4}{|c|}{ Umur (hari) } & \multirow{2}{*}{ Jumlah } \\
\cline { 2 - 6 } Terak & 14 & 28 & 60 & 90 & \\
\hline $0 \%$ & 3 & 3 & 3 & 3 & 12 \\
\hline $20 \%$ & 3 & 3 & 3 & 3 & 12 \\
\hline $40 \%$ & 3 & 3 & 3 & 3 & 12 \\
\hline $60 \%$ & 3 & 3 & 3 & 3 & 12 \\
\hline $80 \%$ & 3 & 3 & 3 & 3 & 12 \\
\hline $100 \%$ & 3 & 3 & 3 & 3 & 12 \\
\hline \multicolumn{4}{|c}{ Total Sampel } & 72 \\
\hline
\end{tabular}

Hasil uji bahan

1. Pasir

Pasir berasal dari Muntilan, Magelang. Ukuran maksimal pasir adalah $5 \mathrm{~mm}$, memiliki kadar lumpur kurang dari 5\%, dan bergradasi agak kasar. Hasil uji pasir lebih rinci dapat dilihat pada tabel 2 berikut.

Tabel 2 Pengujian Pasir

\begin{tabular}{lccl}
\hline Uji Bahan & Nilai & Standar & Keterangan \\
\hline Kadar & $1,87 \%$ & $<5 \%$ & Memenuhi \\
Lumpur & & & \\
Kadar Air & $0,33 \%$ & $1-3 \%$ & $\begin{array}{l}\text { Tidak } \\
\text { memenuhi }\end{array}$ \\
Kadar Zat & $0-$ & - & Memenuhi \\
Organik & $10 \%$ & & \\
$\begin{array}{l}\text { Specific } \\
\text { Gravity }\end{array}$ & 2,55 & $2,5-2,7$ & Memenuhi \\
Gradasi & Daerah II & Memenuhi \\
\hline
\end{tabular}




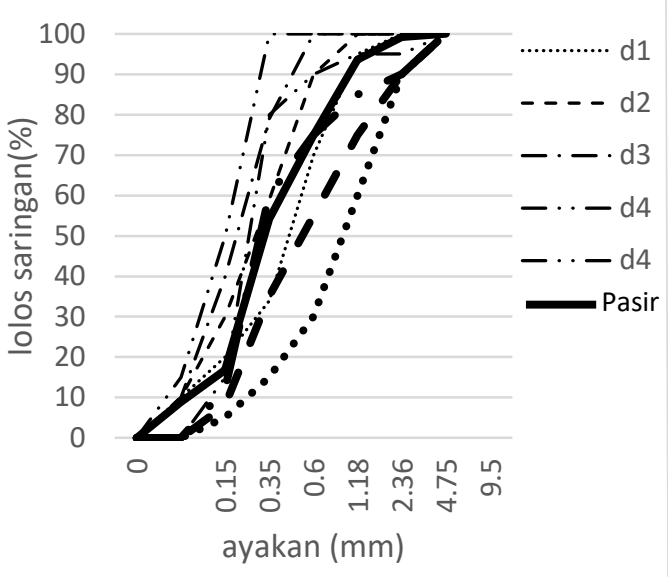

Gambar 2 Gradasi Pasir

\section{Kerikil}

Kerikil berasal dari batu pecah, dari penggilingan batu PT Pancadarma Puspawira kabupaten Karanganyar. Ukuran maksimal agregat adalah $20 \mathrm{~mm}$ dan memiliki berat jenis sebesar 2,54. Pengujian lebih rinci dapat dilihat pada tabel 3 .

Tabel 3 Pengujian Kerikil

\begin{tabular}{lccl}
\hline Uji Bahan & Nilai & Standar & Keterangan \\
\hline $\begin{array}{l}\text { Modulus } \\
\text { kehalusan }\end{array}$ & 4,70 & $6-7,1$ & $\begin{array}{l}\text { Tidak } \\
\text { Memenuhi }\end{array}$ \\
$\begin{array}{l}\text { Specific } \\
\text { gravity }\end{array}$ & 2,54 & $2,5-2,7$ & Memenuhi \\
Abrasi & 9,20 & $<50 \%$ & Memenuhi \\
Absorsi & $1,36 \%$ & $3 \%$ & Memenuhi \\
\hline
\end{tabular}

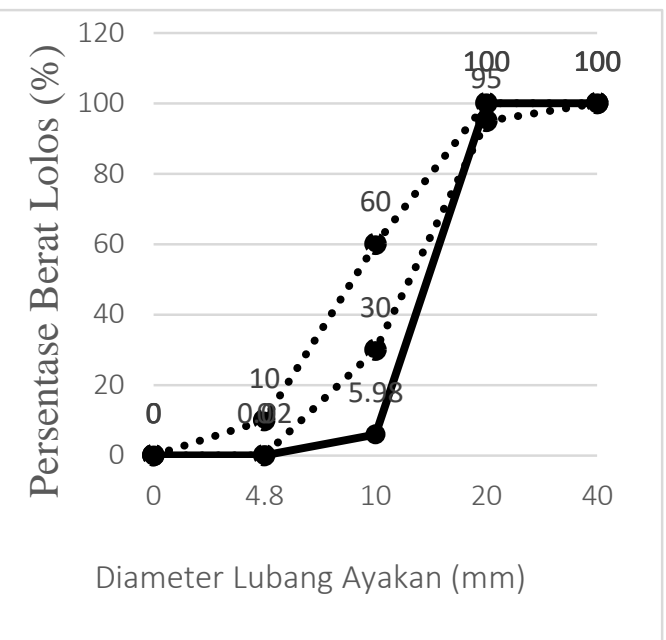

\section{Gambar 3 Gradasi Kerikil}

\section{Terak Baja}

Terak baja berasal dari limbah pengecoran logam dari desa Batur, Ceper, Klaten. Ukuran maksimal berak baja adalah $20 \mathrm{~mm}$ dan memiliki berat jenis sebesar 2,67. Pengujian lebih rinci dapat dilihat pada tabel 4.

Tabel 4 Pengujian Terak Baja

\begin{tabular}{lccl}
\hline Uji Bahan & Nilai & Standar & Keterangan \\
\hline $\begin{array}{l}\text { Modulus } \\
\text { kehalusan }\end{array}$ & 4,31 & $6-7,1$ & $\begin{array}{l}\text { Tidak } \\
\text { Memenuhi }\end{array}$ \\
$\begin{array}{l}\text { Specific } \\
\text { gravity }\end{array}$ & 2,67 & $2,5-2,7$ & Memenuhi \\
Abrasi & 13,45 & $<50 \%$ & Memenuhi \\
Absorsi & $0,31 \%$ & $3 \%$ & Memenuhi \\
\hline
\end{tabular}




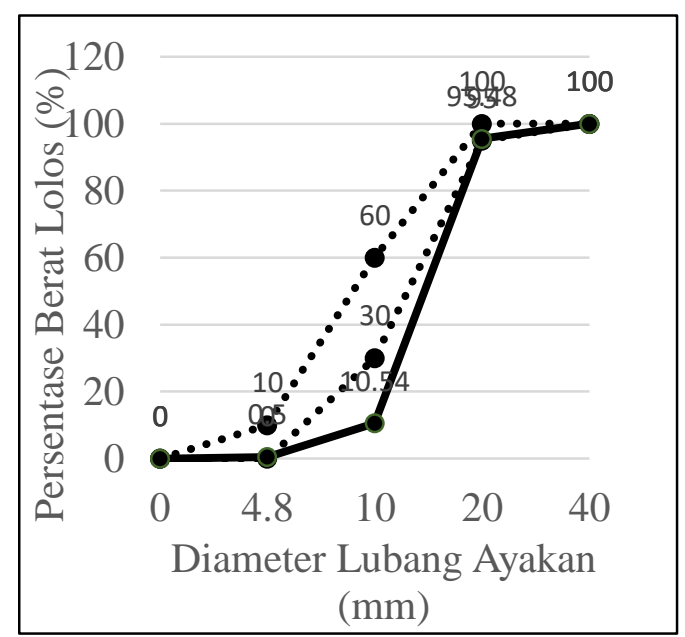

Gambar 4 Gradasi Terak Baja

\section{Uji Kuat Tekan}

Kuat tekan beton merupakan besarnya beban per satuan luas yang menyebabkan beton hancur. Cara pengujian kuat tekan menurut SNI 1974: 2011.

Rumus Perhitungan:

Kuat tekan $=\frac{P}{A} \quad\left(\mathrm{~N} / \mathrm{mm}^{2}\right)$

Keterangan:

$$
\begin{aligned}
& \mathrm{P}=\text { beban maksimum }(\mathrm{N}) \\
& \mathrm{A}=\text { luas penampang }\left(\mathrm{mm}^{2}\right)
\end{aligned}
$$

\section{Uji Berat Isi}

Berat isi beton merupakan perbandingan massa beton dengan volume beton. Rumus Perhitungan:

Berat isi beton $=\frac{m}{v} \quad\left(\mathrm{~kg} / \mathrm{m}^{3}\right)$

Keterangan:

$$
\begin{aligned}
& \mathrm{m}=\text { massa beton }(\mathrm{kg}) \\
& \mathrm{v}=\text { volume beton }\left(\mathrm{m}^{3}\right)
\end{aligned}
$$

\section{HASIL DAN PEMBAHASAN}

Kuat Tekan Beton Terak

Hasil pengujian kuat tekan rata-rata beton terak di tampilkan pada grafik berikut.

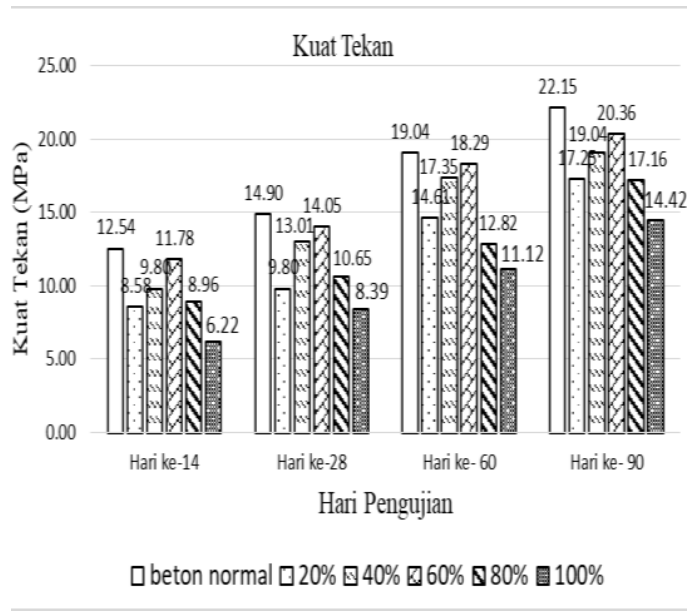

Gambar 5 Kuat Tekan Beton

Dari gambar 5 hasil pengujian kuat tekan rata-rata beton terak yang di tampilkan diatas, dapat dilihat bahwa penggantian terak baja pada persentase $60 \%$ cenderung memiliki kuat tekan optimal setiap umur pengujian. Hal ini terjadi karena nilai slump pada persentase $60 \%$ lebih rendah dari pada nila slump pada persentase penggantian terak 20\%, $40 \%$, $80 \%$, dan $100 \%$. Nilai slump yang tinggi menghasilkan kandungan air terlalu banyak sehingga menyebabkan kuat tekan beton 
menurun. Air yang diperlukan untuk proses hidrasi hanya sekitar $0,25-0,30$ saja dari berat semen, sedangkan sisanya diperlukan sebagai pelumas agar adukan beton mudah dikerjakan (Kardiyono, IV: 1). Akan tetapi jika jumlah air untuk pelumas terlalu banyak pada saat mengeras akan menyebabkan beton berpori sehingga kekuatannya rendah. Terak dalam campuran beton menyebabkan reduksi pori, penggantian terak $60 \%$ pada campuran beton ditemukan sebagai tingkat optimum (Subrami dan Ravi, 2015).

Pada grafik pada gambar 5 diatas, hasil pengujian kuat tekan beton normal cenderung lebih tinggi dari pada beton terak. Hal ini dikarenakan bentuk butiran dan kekuatan agregat. Bentuk butiran agregat yang tajam dan kasar akan meningkatkan ikatan antara agregat dengan pasta semen, sedangkan kekuatan agregat merupakan kemampuan agregat menerima beban. Terak yang digunakan dalam penelitian ini memiliki bentuk butiran tajam dan keadaan permukaan yang licin, sehingga ikatan dengan pasta semen lebih sulit dibandingkan dengan kerikil yang memiliki bentuk butiran tajam dan keadaan permukaan yang kasar. Semakin tinggi variasi penggantian terak maka semakin sulit proses pengerjaannya baik dalam pengadukkan maupun pemadatan. Workability menurun seiring persentase penggantian terak meningkat (Devi dan Gnanavel, 2014).

Penyebab lain karena gradasi kerikil memiliki butir halus lebih sedikit dari pada terak, kerikil memiliki persentase berat butir lewat pada ayakan $4,8 \mathrm{~mm}-10 \mathrm{~mm}$ memiliki persentase $5,98 \%$, sedangkan pada terak memiliki persentase $10,54 \%$. Hal ini menunjukkan terak yang digunakan memiliki butir halus yang lebih banyak, dan menjadi titik lemah pada beton.

Pengujian abrasi merupakan kemampuan agregat kasar untuk menahan beban dari luar atau keausan. Terak yang digunakan dalam penelitian ini memiliki nilai abrasi sebesar 13,45\% lebih besar dari pada nilai abrasi kerikil yaitu sebesar 9,2\%. Abrasi berhubungan dengan 
kekerasan dan ketahan agregat kasar, serta kemungkinan terjadinya pecah pada butir-butir agregat selama pemadatan maupun pengujian. Semakin besar nilai abrasi maka kuat tekan beton semakin berkurang. Dalam penelitian Ratmasari (2013) disebutkan juga abrasi yang besar menghasilkan kuat tekan yang rendah.

\section{Berat Isi Beton Terak}

Hasil pengujian berat isi rata-rata beton terak dapat di lihat pada gambar 6 berikut.

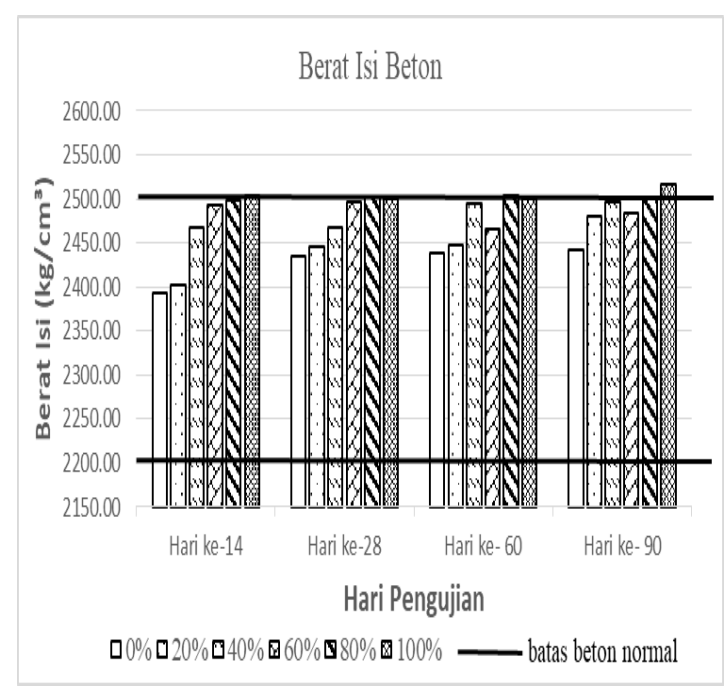

Gambar 6 Berat Isi Beton Terak

Kecenderungan hubungan antara persentase penggantian terak dan variasi umur pengujian terhadap berat isi beton dapat dilihat pada grafik berat isi. Berdasarkan SNI 7656-2012 beton normal adalah beton yang mempunyai berat isi 2200 sampai $2500 \mathrm{~kg} / \mathrm{m}^{3}$. Pada grafik berat isi diatas, bahwa berat isi terendah rata-rata pada presentase $20 \%$ dan masih dalam katagori beton normal, dan rata-rata berat isi tertinggi pada presentase $100 \%$ dan tidak termasuk ke dalam beton normal. Sehingga dalam penelitian ini penggunaan terak baja rata-rata pada presentasse $20 \%$ $60 \%$ masih dalam katagori beton normal, sedangkan $80 \%$ - 100\% tidak termasuk beton normal.

Beton dengan penggantian terak memiliki berat isi semakin tinggi dengan bertambahnya variasi penggantian. Hal ini terjadi karena berat jenis terak lebih besar dari pada berat jenis kerikil, sehingga berat isi beton yang dihasilkan lebih besar beton terak dari pada beton normal dengan kerikil. Penelitian Ratmasari (2013) menghasilkan penggantian terak berpengaruh terhadap berat isi beton dan semakin tinggi variasi penggantian semakin meningkatkan berat isi beton. 


\section{SIMPULAN DAN SARAN}

Simpulan

Berdasarkan hasil penelitian dan pembahasan tentang pengaruh terak baja pengganti agregat kasar terhadap kuat tekan beton normal dengan metode campuran perbandingan 1:2:3 ditinjau berdasarkan umur beton, dapat diambil simpulan sebagai berikut:

1. Pengaruh terak baja sebagai pengganti sebagian agregat kasar dan variasi umur beton berpengaruh terhadap kuat tekan beton.

2. Pada hasil uji berat isi berdasarkan variasi penggantian terak baja dan umur beton menunjukkan pada persentase $20 \%, 40 \%$, dan $60 \%$ penggantian terak masih memenuhi syarat beton normal, sedangkan pada persentase $80 \%$ dan $100 \%$ tidak memenuhi syarat beton normal. Berat jenis beton normal yakni $2200 \mathrm{~kg} / \mathrm{m}^{3}-2500$ $\mathrm{kg} / \mathrm{m}^{3}$ (SNI 7656-2012).

3. Kuat tekan optimal beton terak yaitu pada persentase $60 \%$ di setiap umur pengujian, yaitu
11,78 MPa untuk umur pengujian 14 hari, 14,05 $\mathrm{MPa}$ untuk umur pengujian 28 hari, $18,29 \mathrm{MPa}$ untuk umur pengujian 60 hari, dan 20,36 MPa untuk umur pengujian 90 hari.

Saran

Berdasarkan simpulan dan implikasi hasil penelitian, maka dapat dikemukakan saran sebagai berikut:

1. Perlu adanya penelitian pengembangan jika menggunakan terak sebagai agregat kasar ditinjau dari aspek ekonomis.

2. Perlu dilakukan penelitian lanjutan tentang pemanfaatan limbah terak sebagai bahan bangunan alternatif pengganti pasir dengan metode pencampuran selain metode perbandingan $1: 2: 3$

3. Perlu dilakukan penelitian lanjutan tentang pemanfaatan limbah terak dengan penggunaan zat aditif pada beton.

4. Perlu adanya penelitian lanjutan tentang pemanfaatan limbah terak sebagai bahan bangunan alternatif pengganti agregat kasar terhadap 
beton berat, karena beton dengan penggantian terak memiliki berat jenis yang lebih besar dari pada beton normal.

\section{DAFTAR PUSTAKA}

(2011). Standar Nasional
Indonesia 1974 Cara uji Tekan
Beton dengan Benda Uji
Silinder. Jakarta: Badan
Standarisasi Nasional
(2012). Standar Nasional
Indonesia 7656 Tata Cara
Pemilihan Campuran untuk
Beton Normal, Beton Berat, dan
Beton Massa. Jakarta : BSN

Devi \& Gnanavel. (2014). Properties

of Concrete Manufactured Using Steel Slag. Procedia Engineering, 97, 95-104. Diperoleh pada 3 Agustus 2017, dari

http://sciencedirect.com/scienc e/article/pii/S18777058140328 83

Dipohusodo, Istimawan. (1993).

Stuktur Beton Bertulang. Jakarta :DPU RI

DPU. (1971). Peraturan Beton Bertulang Indonesia. Bandung :
Yayasan LPMB. Bandung : Yayasan LPMB

Herlangga, Heriyawan. (2014). Pengaruh Terak Sebagai Pengganti Agregat Kasar Terhadap Kuat Tarik dan Berat Jenis Beton Dengan Metode Campuran Perbandingan 1:2:3. Skripsi tidak dipublikasikan. Surakarta : Universitas Sebelas Maret Mulyono, Tri. (2004). Teknologi Beton. Yogyakarta: Andi Publishing

Nilforous \& Reza, Muhammad. (2005). The Effect of Micro Silica on Permeability and Chemical Durability of Concrete Used in Corrosive Environment. 24, 02, 31-37. Diperoleh pada 5 Oktober 2017 , dari http://SID.ir

Ratmasari, Puji. (2013). Pengaruh Penggunaan Terak Sebagai Pengganti Agregat Kasar Terhadap Kuat Tekan Beton dan Berat Jenis Beton Normal dengan Metode Campuran 1:2:3. Skripsi tidak 